\title{
Pie Sharing or Food Fight? The Impact of Regulatory Changes on Media Market Competition in Singapore
}

\author{
Marc Edge \\ University of Texas at Arlington, USA
}

\begin{abstract}
The media market in Singapore was deregulated to a limited extent in 2000 when the government there announced the introduction of "controlled competition." Newspaper publisher Singapore Press Holdings (SPH), which for 16 years had enjoyed a government-sanctioned print monopoly, was granted licences for 2 television stations and began broadcasting in both English and Chinese. Government-owned MediaCorp, which formerly held a broadcasting monopoly, was issued a newspaper publishing licence and began publishing a free commuter tabloid titled Today in competition with SPH's broadsheet Straits Times. The start-up losses brought by competition in both media have resulted in heavy financial losses for both firms and have led to government signals that a return to monopoly media might be considered. Some in the Singapore media, along with some scholars there, have argued that the island nation of 4 million is too small as a market to support competing media outlets, particularly in newspaper publishing. This article is an analysis of the Singapore situation in which I argue for a rationalization of media competition there rather than its elimination.
\end{abstract}

The Singapore government loosened its iron grip on mass media in the Southeast Asian city state ever so slightly in 2000 , introducing what was called "controlled competition" to a market that had for decades seen mandated monopolies in both newspaper publishing and television broadcasting (Ang, 2002, p. 246). Granting a newspaper publishing licence to government-owned broadcaster MediaCorp and television licences to newspaper publisher Singapore Press Holdings (SPH) was intended to allow those firms to take advantage of the synergies believed to be inherent in media convergence (Ong, 2000). Three years later, not only had the expected benefits of convergence failed to materialize, but heightened competition for advertising had cut sharply into the profits of both SPH and MediaCorp. This financial squeeze caused many Singaporeans to wonder whether media competition was desirable or even possible in a market of 4 million in population. Before 2003 was over, the government had signaled its willingness to allow a return to the old system of media monopolies, sparking heated public debate both in the media and in scholarly circles.

Address correspondence to Marc Edge, Department of Communication, University of Texas at Arlington, Box 19107, Office 118 Fine Arts Building, Arlington, TX 76019-0107. E-mail: mail@marcedge.com
"If you ask me, the limited media liberalization of recent years has been an expensive experiment," wrote Straits Times columnist Fernandez (2003, p. H15) in responding to the government signals. "The bleeding of the two local media companies has done little good" (Fernandez, 2003, p. H15). The foreign editor of SPH's flagship broadsheet argued that the benefits brought by media competition in 21st-century Singapore had been outweighed by the financial difficulties that accompanied market liberalization:

The undercutting of advertising rates has meant less [sic] resources to recruit, train, and retain much-needed talent. Newsrooms are now doing much more with much less and the strain often shows. ... Will the market sort out these difficulties? I doubt it. To my mind, these are not matters best left to a market free-for-all. (Fernandez, 2003, p. H15)

The signals given by the government brought speculation that a consolidation of media operations was imminent in Singapore, but many in the city state resisted the move, including MediaCorp. Some Singaporeans had long advocated for the introduction of media competition not just to allow market pricing for advertisements but to also bring a more vibrant public sphere than had been seen under the system of monopoly. "Something more impor- 
tant [is] at stake than the fate of these business units," wrote author and former journalist George (2003, p. 32) in a rebuttal to Fernandez published in the Straits Times. "It is Singapore's comfort with competition that is being tested" (George, 2003, p. 32). Arguing in favor of continued competition, the Singapore media critic instead made a case that the new-found freedom had been bungled by media managers:

Let's be blunt about this: Singapore's partially liberalised media industry basically amounts to a duopoly run by chief executives with no prior experience in media management ... whose recent track records in growing new businesses could not be described as confidence-inspiring. (George, 2003, p. 32)

In this article, I examine the competing analyses of the media market in Singapore including those offered in the academic arena. I examine the deregulation debate there in historical and theoretical context and offer recommendations for redressing some of the difficulties encountered with the introduction of media competition.

\section{Background}

Singapore is a $648 \mathrm{~km}^{2}$ island nation of 4 million in population situated near the equator at the tip of the Malaysian peninsula in Southeast Asia. Its small size and lack of natural resources make it dependent on trade, including with Malaysia for its domestic water supply, which is supplied by a pipeline across the narrow Straits of Johor that separate the countries. Singapore and Malaysia were briefly united in the mid-1960s after colonial Malaya received independence from Great Britain in the late 1950s, but the marriage did not last due to ethnic and political incompatibility. The Straits Times, which had expanded from its base in Singapore following World War II to distribute in Malaysia as well, moved its headquarters to Kuala Lumpur in 1959 after Lee Kuan Yew of the People's Action Party (PAP) was elected Singapore's first prime minister. The newspaper's relationship with Lee, whose policies it had opposed editorially, had been tense from the earliest postcolonial days of the PAP (Turnbull, 1995, p. 213). When the 1963 merger between Singapore and Malaysia fell apart 2 years later, the Straits Times found itself in an even more precarious position-headquartered in a foreign country. The newspaper was forced to return its offices to the city state in 1972 after Malaysia limited foreign ownership of its media, leading to the creation of a new Malaysian-owned daily published in Kuala Lumpur titled the New Straits Times in which the Straits Times retained the 20\% interest allowable under the new law (Turnbull, 1995, p. 294). Circulation of each country's newspapers in the other's territory has long been prohibited in Singapore and Malaysia.
Licensing of newspapers was a legacy of colonialism Singapore inherited from Great Britain, but the authoritarian model of press regulation was even more harshly applied under home rule in the city state after Singapore gained independence (Ang, 2002, p. 244). The early 1970s were a watershed era of press repression in Singapore, with several publications stymied by imprisonment of their editors, revocation of work permits for some expatriate journalists, and ultimately cancellation of the embattled Singapore Herald's publishing license in 1971 amidst allegations of foreign influence (Seow, 1998, p. 85). The following year, Lee Kuan Yew issued a stern warning in a speech to the annual Press Club dinner:

Every morning my task begins by reading five-four nownewspapers. And it's a tiresome business. I note the scurrilous, the scandalous. I can live with that. But when any newspaper pours a daily dose of language, cultural, or religious poison, I put my knuckle-dusters on as the first stage. If you still continue, then I say here are the stilettos, choose your weapons. (Seow, 1998, p. 106)

Within months, the government announced the Newspaper and Printing Presses Act (NPPA) under which all newspaper companies were required to convert to public ownership, with only Singaporeans and corporations approved by the government eligible to hold management shares, which controlled editorial policy. A percentage of management shares was also required to be held by government-controlled companies, which placed representatives on the newspapers' boards. In 1977, the act was amended to restrict ownership of shares by any one person to 3\% (Y. S. Tan \& Soh, 1994, p. 37).

The early 1980s saw a series of forced mergers that led to the creation of SPH as a government-controlled newspaper monopoly. In 1982, two competing Chinese dailies were required by the government to join forces under a single holding company, Singapore News and Publications Ltd. (SNPL), which was also handed the New Nation, an afternoon daily that the Straits Times had recently begun publishing. According to Turnbull (1995), who wrote the official history of the Straits Times for its 150th anniversary, the government at first wanted the Straits Times to hand over both its Business Times and the New Nation to SNPL along with their staffs. Such corporate sacrifice was deemed necessary by the government in its quest to promote multiculturalism because it was considered in the national interest that the Chinese-language newspaper group also publish dailies in English. A compromise was finally reached in which only the New Nation was ceded to SNPL without its staff. "In return the [Straits Times] group would be guaranteed freedom from competition in the English-language morning market for three years," according to Turnbull (1995), "and would be permitted to publish its own Chinese-language newspaper" (pp. 
342-343). In 1984, a merger between the Straits Times group and SNPL was announced, leading shocked journalists to demonstrate against the consolidation of all newspapers in Singapore into one publishing company. The government denied it was behind the creation of SPH, but according to former Singapore solicitor general Seow (1998), “Lee's fingerprints could be seen all over the merger agreement" (p. 123). SPH went on the Singapore stock exchange as the country's sixth-largest listed company, its largest industrial group, and its only monopoly.

The foreign press has similarly been targeted for attitude adjustment by the Singapore government, which has severely restricted the circulation of-or "gazetted"-publications whose coverage it has considered unfavorable or even overly political, such as Time, the Economist, the Far Eastern Economic Review, and The Asian Wall Street Journal. Others, such as the International Herald Tribune, have been hit with stiff monetary damages following legal actions commenced for libel after criticizing the Singapore government (Wallace, 1995). The PAP's tight grip on media in the city state has helped it to retain political power continuously since 1959 in a de facto, one-party system. This harsh press repression has earned Singapore not only international scorn but also annual rebuke in the form of press freedom rankings. Freedom House regularly rates the city state near the bottom of its scale, grouped in the "not free” category with countries such as Russia, Colombia, and Sierra Leone. Singapore's score in recent years has been 66 out of 100, based on three criteria of constraints on each of which it scores almost equally poorly: legal environment (24); political influences (21); and economic pressures (21; Karlekar, 2003, p. 135).

\section{Market Liberalization}

In mid 2000, the Singapore government decided to loosen slightly its restrictions on the island nation's media at least in terms of economic constraints. In June of that year, it announced that limited media competition would henceforth be allowed, granting a newspaper licence to MediaCorp, which is controlled by the government through its private-sector arm Temasek Holdings, and radio and television licences to SPH (Ang, 2002, pp. 246-247). Almost immediately, MediaCorp announced it would begin publishing by year's end a free commuter tabloid titled Today in partnership with local transit companies (Ong, 2000). Four months earlier, SPH had been granted a licence to publish as an 11th newspaper a morning tabloid titled Project Eyeball, which was aimed at "younger, Net-savvy readers" and included a continuously updated Internet edition (Khalik, 2000). However, even before it began publishing in August, the promised new competition from MediaCorp put SPH in a quandary with Project Eyeball, which had been priced at 80 cents compared with only 60 cents for the thick broadsheet Straits Times (Edge, 2004b). MediaCorp's free commuter tabloid promised to rob Project Eyeball of much of its market, so 2 days after Today was announced, SPH management decided it would begin publishing its own giveaway tabloid titled Streats. The decision effectively doomed Project Eyeball, which achieved a circulation of only about 20,000 before folding in June 2001 after only 10 months of publication (Edge, 2004b). Despite conceiving it after MediaCorp announced it would begin publishing Today, SPH hit the streets with Streats on September 2, 2000, more than 2 months before its new competition appeared in November due largely to the publishing giant's advantage of having an extensive newspaper staff and plant already in place. MediaCorp countered SPH's first-mover edge, however, by giving away Today at stations along Singapore's extensive light-rail transit line operated by Singapore Mass Rapid Transit, its largest partner in the new publication.

In early 2001, the first financial results in the media war of attrition were reported, with SPH's first-half profits falling \$19 million Singapore dollars (S\$; approximately U.S.\$10 million) due largely to start-up losses of S\$2.9 million for Streats, S\$4.8 million for Project Eyeball, and S\$9.5 million for its MediaWorks television arm (Low, 2001). By the time SPH announced the closure of Project Eyeball in June, it had lost a total of S\$13.3 million on the start-up daily (Rajeev, 2001). When SPH's financial year-end results were announced in October, the losses had increased to S\$42.5 million for MediaWorks-which chalked up revenues of only S\$16.6 million-and $\$ \$ 5.6$ million for Streats. The resulting $18.7 \%$ drop in its profits to $\$ \$ 340.8$ million prompted SPH to embark on a \$\$35-million cost-cutting program including wage cuts for two thirds of its 4,300 employees (Teh, 2001b). Today was also debilitating the financial fortunes of its investment consortium by an estimated S\$22.2 million in its first 11 months of operation (“Today Drags Down Profits," 2001).

After a year of competition, Streats held the advantage in readership, as surveys by AC Nielsen estimated it had captured $14 \%$ of the market with 408,000 readers compared with 346,000 readers and $11 \%$ coverage for Today (Teh, 2001a). However, by 2002, according to AC Nielsen, those positions had been reversed, with Today enjoying a readership of $16 \%$ and Streats only $11 \%$ ("Consumption of Media,” 2002). Streats then underwent a revamp to make it more of an up-market product and thus more similar to Today, and 6 months later, in March 2003, SPH published figures that claimed its readership had leapt by one half to 554,000 (Quah, 2003). Two months after that, in mid-May, SPH claimed that readership of Streats had almost jumped by one half again to 800,000, which amounted to almost three readers for every one of the 280,000 copies it printed (W. Tan, 2003). MediaCorp questioned the survey's methodology, which SPH and market research firm Synovate refused to disclose, insisting only 
that it adhered to "professional research standards" (Divyanathan, 2003). Streats trumpeted the 800,000 figure on its front page until Nielsen's revised estimate of its readership came in at the end of June at less than half that number-392,000 (Yap, 2004). MediaCorp was similarly accused by SPH of fudging the figures when it claimed that a readership of 580,000 made it the "undisputed second most widely read daily English newspaper in Singapore" (Ng, 2003, p. H7). Today executives quickly amended that claim to "second-highest morning daily" (p. H7) when SPH pointed out that its tabloid The New Paper, which it had started in 1988, had an average readership of 456,000 (Ng, 2003).

Competition between the commuter tabloids for advertising was also fierce, with Today almost bending over backward to attract business onto its pages. According to the industry magazine Media, advertisers appreciated the "flexibility" offered by the MediaCorp tabloid. "Today advertisers are allowed to run 'island' ads, ads at the top of the page, flags, wrap-arounds and advertorials. Other innovations Today has implemented include letting Dell computers run a front-page wrap around with "Tomorrow' as the masthead [sic]" ("Dailies Bank On Facelifts," 2002 , p. 10). In its quest for advertisers, Today even sold its entire issue of March 24, 2003 to HP for use in the computer company's "Everything is possible" branding campaign, turning its tabloid pages broadsheet for a day and printing its front-page "flag" in HP blue instead of its regular red (Said, 2003). By the end of that month, increased advertising revenues had helped Today trim its yearly loss to $S \$ 10$ million from S\$18.8 million ("MediaCorp Posts," 2003).

In broadcasting, SPH was on the other side of the uphill climb inevitably faced by new entrants to a market. The channels broadcast by its subsidiary MediaWorks immediately gained solid viewership, with its Channel U actually outdrawing MediaCorp's Chinese-language Channel 8 by July 2002, according to AC Nielsen. Its English-language Channel i, however, lagged far behind MediaCorp's flagship Channel 5, with only $25 \%$ of viewership. More important, MediaCorp's dominant position in the market allowed it to retain more than $85 \%$ of television advertising sales. However, due to a deepening recession, even MediaCorp's local television operations (it also operates the regional network Channel News Asia) showed a S\$65-million loss in 2002 compared with a $\$$ \$35-million profit the previous year (Low, 2002). Competition for broadcast advertising was also fierce, fuelled by a protracted demand slump. In late 2003, HSBC Bank issued a report estimating the average discount rate for advertising in the city state that year had been 37\% (Leng \& Pek, 2003).

In an attempt to level the uneven playing field of media competition between the entrenched players and the new entrants, the Singapore government introduced a compe- tition code in 2003, which had been lobbied for by MediaCorp in response to rate cutting by SPH for advertising in Streats (Siow, 2002). Under the code, archived editorial material had to be shared by the established media outlets with their new competition, and the dominant player in each medium was prohibited from undercutting advertising rates. "Predatory pricing," which was defined as selling products below cost to stymie emerging competition, was expressly forbidden under the new code but only of the established companies, not the new entrants, which brought protests from SPH (T. H. Tan, 2003).

\section{Cooling Competition}

SPH first began signaling its desire for a cease fire in the Singapore media war in late 2002, suggesting it would be willing to get out of the television business if MediaCorp left the newspaper field. SPH executive chairman Lim Kim San said, "We are bleeding. Both Streats and Today are bleeding. And in TV we are also bleeding. So we are wasting our resources" (W. K. Wong, 2002, p. 8). In June 2003, SPH announced the layoff of 111 employees to save $\$ \$ 5.7$ million annually. It was the third mass layoff in as many years for SPH, following downsizings of 97 in 2002 and 116 in 2001 (Khalik, 2003). In October, the company's annual report showed that although the losses incurred on its MediaWorks television operations had narrowed to $S \$ 40.2$ million from $S \$ 44.6$ million in the previous year, the red ink spilled by Streats over the previous year had increased to $\$ \$ 5.8$ million from $\$ \$ 5.2$ million (Koh, 2003).

In mid-November, the government signaled that it would be willing to allow a return to monopoly operations in the media after 3 years of costly competition. Minister for Information, Communications and the Arts, Lee Boon Yang, indicated in a speech to the Singapore Press Club that the government would be open to allowing consolidation between SPH and MediaCorp to reduce the competitive environment. "Wherever we can, we will try to promote and encourage competition, but we are also realistic and if competition does not work, then, well, we have to accept that the market itself is just too small to accept more than one significant player" (Lim, 2003, p. 1). Founding prime minister Lee Kuan Yew, who was still active in the government at age 80 as Senior Minister, said in an interview broadcast on television that evening that he had doubted from the beginning whether media competition would be possible in Singapore due to the small size of the market. The officially expressed doubts were enough to spark widespread speculation that a media consolidation was imminent in the micromanaged city state. The pronouncement by Lee Kuan Yew particularly led many to believe it was a fait accompli, so great was his influence in the fledgling nation he personally shepherded from third-world to first-world status through 
three decades of leadership. As political analyst Seah Chiang Nee told Reuters, "When Kuan Yew says something, traditionally he is not offering an opinion" (Espina, 2003).

However, SPH denied it was negotiating to acquire MediaCorp ("SPH says," 2003). Its chairman, Lim Chin Beng, also declared the media giant had no intention of getting out of the television business, saying SPH was in TV for the long term, calling it a "strategic" platform given the waning influence of print (W. K. Wong, 2003). For its part, MediaCorp insisted it was not about to merge with or sell out to SPH, nor did it intend to fold Today, although its CEO did express an interest in taking over the television assets of SPH if it decided to bow out of the medium (A. Tan, 2003). The influence of shareholders and investment analysts also began to be felt by SPH, with discontent expressed at its annual general meeting in December about the idea of buying more broadcasting assets. Complained one shareholder: "Broadcasting is cash draining. If you buy another broadcasting business, you'll be carrying an albatross around your neck" (W. K. Wong, 2003, p. 1). A survey of investment analysts taken by the Business Times showed that most believed there was room for competing players in each medium, but that some of the behavior seen so far in the Singapore media war had been anticompetitive:

What investors really want, the analysts said, is an end to the severe price discounting in the media industry. They said the main hurdle to commercial viability is not the capacity of the market but severe price wars, especially in broadcasting. ... "In markets like the U.S., it would be an anti-trust situation, where you're operating at a loss to drive someone out of competition," [one] said. "The pie is big enough to go around, but they'd rather have a pie fight than share the pie." (W. K. Wong \& Lim, 2003, p. 2)

The poor financial results led many to question whether the formerly entrenched monopolists possessed the acumen required to compete in a market environment. The trade journal Media even asked, "Have the two incumbents done their sums right? ... Do both sides have the necessary top and middle management talent, with enough media experience, to exploit growth opportunities presented by a deregulated environment?" "Has Time Come," 2003, p. 4). The model some critics claimed should have been followed in deregulating the Singapore media market in 2000 was the one followed successfully there in 1997 in telecommunications. From a government-run monopoly dominated by SingTel, a more orderly introduction of competition was seen from the outset due to rules that ensured a level playing field. "The free-for-all in mobile telephony has also spurred innovation," noted The Edge (Leng \& Pek, 2003, p. 5), a Malaysian business weekly. "And when it comes to calling overseas, prices have never been cheaper. According to government data, international direct dial rates to popular destinations around the world have fallen by up to $80 \%$ since the telecoms market was fully liberalized" (Leng \& Pek, 2003, p. 5). The difference, according to George (2003), was that in telecommunications, the competition came from multinational companies, which are prohibited from investing in Singapore's mass media:

Foreign investors will enter only on condition that government policies are transparent and former government-linked monopolies do not exercise an unfair advantage. ... The government may have felt less pressure to carry out media liberalization with the same nurturing touch it had applied to telecoms. (p. 32)

Some called for foreign ownership to be allowed into the media market as well. Mused Media: "Perhaps the time has come to take deregulation a step further. If the Government is serious about media competition, the time is right to consider opening the media door to foreign players with the ability to inject investment dollars into the industry" ("Has Time Come," 2003, p. 4). Today even ran an analysis by Australian scholar Backman (2003), headlined "Is Singapore Paranoid," in which he called for an end to licensing of newspapers under the NPPA and for foreign competition to be allowed into the market, referring to the city state's government control over media as "the old fashioned, outmoded trappings of a Third World dictatorship" (p. 3).

In November 2003, SPH reported that its first quarter print revenues had slipped another 3\%, and that its broadcasting losses had widened to $\$ \$ 10$ million from $\$ \$ 6.3$ million for the quarter. In an attempt to stem the tide of red ink arising from competition in both the newspaper and broadcasting fields, SPH announced in January 2004 a cover price increase for 9 of its 11 newspapers, including Sunday editions. The newsstand price of its flagship Straits Times, which in 2002 had a paid circulation of 385,000, was increased 33\% to 80 cents (Paul, 2004).

\section{Economic Theory}

In early 2004, the media competition debate in Singapore took to the academic arena, and theorists in the city state also disagreed on whether the island nation was large enough to sustain competing media players. Ang and Fu (2004a, 2004b) published a two-part analysis in the Straits Times in which they argued that the problems brought by media competition were behavioral in television but structural in newspapers. As a result, Ang and Fu (2004a) concluded that television broadcasting in Singapore was well capable of supporting more than one player and that eventually an equilibrium position would be reached be- 
tween the competing firms. MediaCorp and SPH were bleeding red ink in television only in the short term, Ang and Fu (2004a) argued, due to their "overly enthusiastic behaviour in pricing and bidding" in a "frenzied market-share battle" (p. 12). In the newspaper business, however, Ang and Fu's (2004b) analysis was reversed. Higher start-up costs and lower marginal costs meant that Today would never be able to compete with SPH due to the "circulation spiral," which sees advertisers and then readers and then more advertisers gravitate to the largest daily in a market:

To defy this downward spiral, a paper like Today needs to pour in a fearsome amount of money, which may not be recovered if market fundamentals do not change favourably. ... The Singapore newspaper market will probably not develop into a truly competitive market without some structural intervention. (Ang \& Fu, 2004b, p. 16)

Part of the problem in the Singapore media war, Ang and Fu (2004a) added, was that "perhaps unexpectedly" the battle for television advertising had spilled over into the newspaper business, which had an unintended effect when competition on price turned predatory. "Under-priced advertising airtime siphoned off sizeable newspaper advertising sales from SPH. ... No market is ever large enough to be profitable if companies undercut each other's price below costs" (Ang \& Fu, 2004a, p. 12). To redress the imbalances in newspaper competition, Ang and Fu (2004b) offered three possible solutions:

- A U.S.-style Joint Operating Agreement between SPH and MediaCorp Press, under which Today could benefit from the same vertical integration and economies of scale enjoyed by the SPH dailies while still competing editorially.

- Dividing the newspaper market linguistically between SPH and MediaCorp, with one taking the English-language market and the other the Chinese newspapers.

- Enlarging the MediaCorp stable of publications in other ways, such as with a chain of weekly magazines, to increase its economies of scale.

A dissenting scholar (Edge, 2004a) argued that Singapore was large enough as a market to sustain competing players even in newspaper publishing given the demonstrated success of tabloids as second-place newspapers in other countries. Citing the success of the Toronto Sun chain of morning tabloids in his native Canada, Edge (2004a) argued in an analysis published in Today that the natural monopoly theory of newspapers had been effectively repealed there and replaced by a paradigm of product differentiation and niche marketing. By appealing to a younger readership, the Sun tabloids had proven profit- able, Edge (2004a) pointed out, by reaching a demographic that was not being served effectively by broadsheets and was coveted by advertisers for its disposable income. Giveaway commuter tabloids in particular had proven in many countries to be a viable model for differentiated newspaper competition, Edge (2004a) added, as seen with the worldwide success of Sweden's Modern Times Group, which had provided the template for both Today and Streats:

The solution to the media problem in Singapore is not more government regulation, but less. Media businesses must be allowed to manage their own affairs, or mismanage them as the case may be. Left alone, market forces will sort things out. A market approaching four million in population is more than large enough to support at least two newspapers, but neither will be as profitable as a monopoly daily. Get used to it. (p. 17)

\section{Politics and Culture}

Economic theory is only one level on which media competition must be considered in postcolonial Singapore, as normative considerations must also be taken into account. Politics are an inescapable reality in a nominal democracy that has not seen a change in its ruling party since gaining independence in 1959. Culture is another crucial variable in the multiethnic republic, which saw race riots in the 1950 s and 1960s result from tensions, sometimes fanned by the press, between the country's Malay Muslim minority and its Chinese majority. Media competition in Singapore must be viewed as a kind of multilevel chess game with economic considerations constituting only the most apparent variables and political and cultural factors playing themselves out on underlying levels. In this article, I deal explicitly only with economic issues, as normative considerations of press freedom must be left to Singaporeans to reconcile. The complexity of political and cultural issues in Singapore must be recognized at least implicitly, however, even by the economist.

In an attempt to foster the twin goals of ethnic harmony and economic growth, the Singapore government has historically taken an interventionist hand in the nation's press to a point where some scholars have considered that it qualifies as an authoritarian regime under the old four theories of the press (Hachten, 1996, p. 17). Others have felt it conforms more closely to the "development" model due to the explicit onus placed on the press to contribute to nation building. Some scholars, however, have doubted the applicability of the development press model to Singapore because its expectations of uncritical journalism are supposed to lapse after a nation grows into adulthood, and as one of the leading "Tiger economies" of Asia, the city state graduated to developed nation status 
decades ago. As Bokhorst-Heng (2002) noted, "The use of the term 'development model' suggests that at some higher stage the press in Singapore will move to a more advanced press model" (p. 564). Another model offered to explain press performance in Singapore has been the "Asian values" paradigm under which the media are expected to demonstrate respect for authority, foster harmony, and build consensus in contrast to Western models that expect the press to perform a "watchdog" function in a more adversarial system. One study (Massey \& Chang, 2002) of online newspapers in the region, however, found that Asian values in journalism (as reflected by a lack of conflict as a central story-telling device) correlated more closely with measures of press freedom than with geography. Countries with a press rated not free, such as Singapore and Malaysia, also had a press that was more supportive of the government in contrast with neighboring nations with a freer press, which demonstrated fewer Asian values (Massey \& Chang, 2002, p. 999).

\section{Analysis}

Straits Times columnist Fernandez (2003) engaged in some disingenuousness when he claimed that the assumption on the part of many that SPH is state owned and controlled is mistaken because "the bulk of its shares is owned not by Singaporeans, but foreigners, mainly institutional players" (p.H15).The truth is that non-Singaporeans are prohibited from owning management shares in SPH, which carry 200 times the voting power of common shares, and that the holders of these "golden" shares must be approved by the government under the NPPA. As George (2000) noted in his book Singapore: The Air-Conditioned Nation, this provision in the law allows the government to actually determine the composition of SPH's board of directors:

\footnotetext{
It [the NPPA] has been so effective in fulfilling its objective of behind-the-scenes control that most Singaporeans are not even aware of it, even though it is the main instrument shaping how the press operates. ... With this mechanism in place, the government needs neither to post its officials directly into top newsroom positions, nor to nationalize the press. (p. 66)
}

George (2000) noted that the quid pro quo for press acquiescence to controls on its freedom in Singapore was monopoly profits. "A press allowed to make money out of a system will support that system [as] publishers value their bottom line more highly than they do their editorial freedom" (George, 2000, p. 67). If competition is to be allowed at all in the Singapore press, monopoly profits will no longer be made, and the press will thus be less likely to accept restrictions on its editorial freedom and thus its pursuit of commercial success.
K. K. Wong (2001) identified the fundamental contradiction of postcolonial Singapore as the city state's openness to foreign commerce through duty-free trade policies at the same time as it restricts the flow of information in the domestic media. K. K. Wong developed a theory of "controlled commodification" to explain media and culture in Singapore and claimed that the pursuit of economic prosperity in the city state has been at the expense of "depoliticization" of the public sphere in Singapore. State control of media through its controlling corporations has seen a mandated "political-economic separation" under which the media are proscribed from covering politics in the pursuit of the nation's economic ends. "PAP state control has been legitimized and internalized in the industry as part of the country's press policy, which is largely to serve PAP economic control in the name of Singapore's survival" (K. K. Wong, 2001, p. 96). When Mahbubani's provocatively titled book, Can Asians Think?, was first published in Singapore in 1998, it caused a stir not only in the city state but also regionally and even worldwide. A more appropriate question to ask in considering media competition in Singapore, however, might be "Can Asians think critically?" Mahbubani, who is Singapore's ambassador to the United Nations, challenged the "end of history" view that sees the American empire as the pinnacle of human advancement, and his book has since been republished around the world. The fact that his question sparked the discussion it did amply demonstrates the importance of asking critical, even insulting, questions in the search for useful answers.

Singapore's economic achievements have proven beyond doubt the financial acumen of its leaders, but the success has come at a considerable social cost due to government micromanagement not only of industry but also of the public sphere. Dissent to the government's economic and social policies has not been permitted under a controlled press, but when the former policies fail, all that is lost is financial. Misguided social policies that go unchallenged can result in long-term structural problems such as the city state's current "baby bust," which is a result of government admonitions against having large families in the 1960s. Constructive criticism of and even vigorous disagreement with government policies is essential for a healthy democracy and would be a social good in and of itself in addition to a needed critical counterbalance to the city state's traditional tendencies toward "groupthink." For effective reform of media competition to take place in Singapore, the draconian restrictions of the NPPA must first be abolished. Micromanagement of the market by the issuing and revoking of newspaper licenses creates an artificial barrier to entry and through self-censorship has the effect of turning the nation's press into less of a critical watchdog and more of a government lapdog. The requirement for government representation on newspaper boards of 
directors similarly should be dropped for Singapore to free the press from official oversight.

However, there is good reason not to push the limits of cultural flexibility too far. The suggestion that allowing foreign ownership of Singapore media can cure what ails it is unrealistic given the cultural and political constraints facing the city state. The suggestion of Backman (2003) and others is bound to fail given not only some considerable xenophobia extant in the city state but also due to its small size and precarious position geopolitically. Control of any nation's press is a privilege that is rightfully reserved for nationals only, despite the fact that some countries, such as the United States, allow newspapers to be owned by foreigners. The depth of resistance in Singapore to Backman's (2003) suggestion can be seen in the official reaction to it. In the same speech in which he bruited an end to media competition, Minister for Information, Communications and the Arts Lee Boon Yang declared the government's opposition to foreign ownership of media in no uncertain terms. "By attacking the Government's media policy and urging the adoption of the Western model, he had clearly crossed the line and engaged in our domestic politics" (Lee, 2003). The twin topics of foreign ownership and the possible return of monopoly media dominated press coverage in and about Singapore for days, with the question of media competition proving more enduring-and open. The importation of foreign expertise in media management should be considered in Singapore, however, beyond the ad hoc hiring of contract managers and consultants. Only through an ownership stake will multinational corporations lend their most self-interested expertise, but that equity position need not be a majority. Even minority ownership would no doubt help to attract foreign investment, and the resulting injection of outside perspective into media management could be beneficial.

Ang and Fu (2004b) were correct in their assessment that the newspaper market in Singapore will probably not develop into a truly competitive market without some structural intervention. However, following Ang and Fu's (2004b) suggestion of adding Today to what is undoubtedly already the largest jointly operating newspaper publishing company in the free world would likely do little to ameliorate the circulation spiral, which has been seen to continue in effect in joint operating agreements (JOAs) in the United States (Lacy \& Simon, 1993, p. 99). Folding Today into the SPH stable of dailies in a JOA would mean an effective end to competition; and although it might preserve one editorial voice (although that is also unlikely, as SPH would doubtless close Streats under this scenario), it would inevitably see a return to monopoly price fixing for advertising, as has been seen in many United States markets (Picard, 1989, p. 81). The sharing of advertising revenues by SPH with MediaCorp under competition may mean that it no longer enjoys the monopoly profits it reaped for
16 years, but in the long term, it will benefit not only other media firms in Singapore but also advertisers by shifting that prosperity around.

Ang and Fu (2004b) noted that their suggestion of dividing the press in Singapore along linguistic lines suffers from the drawback of the decline in readership seen of Chinese newspapers recently, which would tend to disadvantage the company publishing them. However, it would also be a perilous move culturally and politically, as ethnic divisions are something the press in Singapore has historically been charged with reducing rather than enhancing. Ang and Fu's third way of solving the media competition conundrum in Singapore, by reducing the size disparity between the players in the newspaper field, perhaps holds more promise. However, adding a few weekly magazines to MediaCorp Press to allow it sufficient size to afford its own printing plant would hardly afford it the economies of scale enjoyed by SPH.

\section{Conclusion}

SPH is not only one of the world's largest newspaper publishing companies, it is also one of the wealthiest, due to the profit levels of $40 \%$ to $50 \%$ it often rang up during the 16 years it enjoyed a newspaper monopoly in Singapore. Even since deregulation and with its start-up losses in television and tabloids, SPH recorded a healthy $15.7 \%$ return on revenue before extraordinary items in its 2003 fiscal year (Koh, 2003). As a result, it has cash reserves estimated at $\$ \$ 450$ million along with investments in foreign media companies and extensive holdings of valuable Singapore real estate including a shopping mall estimated to be worth $\$ \$ 1$ billion (Paul, 2004). Its ability to continue waging the media war of attrition in Singapore is enormous, limited only by the will of its shareholders to endure lower earnings in the short term. As for MediaCorp, which does not report publicly, its cash reserves have been estimated at $\$ \$ 200$ million as a result of the monopoly profits it reaped for decades in television (Paul, 2003). Thus, both players have the financial wherewithal to endure losses in their start-up media ventures for many years. The question becomes whether the government will intervene and rationalize media competition in Singapore. It has shown no hesitation to orchestrate the industry in the past, and its suggestions of November 2003 indicated to many that just such a reorganization was imminent. Yet rather than pull the plug on competition, a more effective way of meeting the needs and wants of all stakeholders, and not just the media players, might be to instead better level the playing field for competition.

Instead of a merger between SPH and MediaCorp Press, the advantages already seen of media competition-not only in the market for information but also in the market for advertising-can only be continued through an equal- 
ization in the size of the competitors. Instead of dividing the press in Singapore between English-language and Chinese newspapers, if MediaCorp were to be ceded some of the ethnic language dailies now published by SPH along with a serious broadsheet such as the Business Times, it may have a better chance of financial viability in the long term. Folding Streats might also help to balance the situation, as under fair competition rules from the outset, its publication might not have even been allowed. However, in the end, it is not Singapore politicians who will decide the fate of media competition in the city state but Singapore citizens. If Singaporeans decide to support Today by reading it and businesses decide to patronize its pages by placing advertisements, newspaper competition is bound to not only survive but thrive.

\section{Marc Edge \\ (mail@marcedge.com)}

is a Visiting Assistant Professor in the Department of Communication at the University of Texas at Arlington, Arlington, TX. He studies newspaper competition and is the author of Pacific Press: The Unauthorized Story of Vancouver's Newspaper Monopoly (Vancouver, British Columbia, Canada: New Star Books, 2001).

\section{References}

Ang, P. H. (2002). Media and the flow of information. In D. da Cunha (Ed.), Singapore in the new millennium: Challenges facing the city-state (pp. 243-268). Singapore: Institute of Southeast Asian Studies.

Ang, P. H., \& Fu, W. (2004a, February 11). Singapore's TV market: One player or two? Straits Times, p. 12.

Ang, P. H., \& Fu, W. (2004b, February 12). Newspaper publishing in S'pore: One player or two? Straits Times, p. 16.

Backman, M. (2003, October 8). Is Singapore Paranoid? Today (Singapore), p. 3.

Bokhorst-Heng, W. (2002). Newspapers in Singapore: A mass ceremony in the imagining of the nation. Media, Culture \& Society, 24, 559-569.

Consumption of media boosted by deregulation. (2002, October 18). Media, p. 12.

Dailies bank on facelifts. (2002, October 4). Media, p. 10.

Divyanathan, D. (2003, May 26). SPH stands by Streats' 800,000 readership figure. Business Times (Singapore), p. 5.

Edge, M. (2004a, February 14-15). An enduring success story: The little newspaper that could. Today (Singapore), pp. 16-17.

Edge, M. (2004b). The failure of Project Eyeball: A case of product over-pricing or market over-crowding? International Journal on Media Management, 6, 114-122.

Espina, K. (2003, December 5). Singapore considers return of monopoly in media. Reuters News Service.
Fernandez, W. (2003, November 15). Media "golden age" looking tarnished. Straits Times, p. H15.

George, C. (2000). Singapore: The air-conditioned nation. Singapore: Landmark Books.

George, C. (2003, November 22). Give media competition a genuine chance. Straits Times, p. 32.

Hachten, W. A. (1996). The world new prism: Changing media of international communication (4th ed.). Ames:Iowa State University Press.

Has time come to open media door? (2003, November 28). Media, p. 4.

Karlekar, K. D. (Ed.). (2003). Freedom of the press 2003: A global survey of media independence. New York: Freedom House. Available at http://www.freedomhouse.org/pfs2003/pfs2003.pdf

Khalik, S. (2000, February 6). New SPH paper gets its licence. Straits Times, p. 2.

Khalik, S. (2003, July 1). SPH lays off 111 staff to stay lean. Straits Times, p. 4.

Koh, E. (2003, October 11). SPH earnings rise $23 \%$ to $\$ \$ 379 \mathrm{~m}$. Straits Times, p. A29.

Lacy, S., \& Simon, T. F. (1993). The economics and regulation of united states newspapers. Norwood, NJ: Ablex.

Lee, B. Y. (2003, November 13). Media free-for-all? No, our values can't be sacrificed. Straits Times, pp. 20-21.

Leng, S. S., \& Pek, T. G. (2003, November 24). Free to choose? The Edge (Singapore), p. 5.

Lim, K. (2003, November 15). Govt open to ending rivalry in media industry. Straits Times, p. 1.

Low, E. (2001, March 27). SPH interim net earnings slip 8.5\% to $\mathrm{S} \$ 204 \mathrm{~m}$. Business Times (Singapore), p. 4.

Low, E. (2002, September 27). MediaCorp loss widens to S\$120m from S\$19m. Business Times (Singapore), p. 2.

Mahbubani, K. (1998). Can Asians think? Singapore: Times Books International.

Massey, B. L., \& Chang, L. A. (2002). Locating Asian values in Asian journalism: A content analysis of Web newspapers. Journal of Communication, 52, 987-1003.

MediaCorp posts S\$134.4m net profit after SCV sale. (2003, August 5). Business Times (Singapore), p. 9.

Ng, J. (2003, October 9). ST is the No. 1 paper, now for the No. 2 ... . Straits Times, p. H7.

Ong, C. (2000, June 6). Broadcast licences for SPH, newspaper licence for MediaCorp. Business Times (Singapore), p. 1.

Paul, B. (2004, January 19). SPH - Between a rock and a hard place. The Edge (Singapore), p. 7.

Picard, R. (1989). Media economics: Concepts and issues. Newbury Park, CA: Sage.

Quah, M. (2003, March 4). Streats readership surges 50\%. Business Times (Singapore), p. 4.

Rajeev, P. (2001, June 28). SPH to suspend operations of Project Eyeball Newspaper-Singapore media firm cites market conditions. Asian Wall Street Journal, p. M2.

Said, S. (2003, March 24). S'pore Tabloid “Today” goes broadsheet. Bernama Daily (Malaysia), p. 4.

Seow, F. T. (1998). The media enthralled: Singapore revisited. London: Rienner.

Siow, D. (2002, April 11). Singapore tabloid girds to stir media competition. Reuters News Service.

SPH says it is not in talks to buy MediaCorp. (2003, November 15). Business Times (Singapore), p. 4. 
Tan, A. (2003, December 9). MediaCorp CEO rules out merging with SPH or giving up Today. Straits Times, p. A15

Tan, T. H. (2003, January 11). OK, let's keep this media fight fair and clean. Straits Times, p. H18.

Tan, W. (2003, May 13). Sharp jump in readers, ads for revamped Streats. Straits Times, p.6.

Tan, Y. S., \& Soh, Y. P. (1994). The development of Singapore's modern media industry. Singapore: Times Academic Press.

Teh, H. L. (2001a, October 3). Channel U now second in TV viewership-AC Nielsen. Business Times (Singapore), p. 10.

Teh, H. L. (2001b, October 17). Start-up losses drag SPH earnings down 18.7\%. Business Times (Singapore), p. 4.

Today drags down profits. (2001, October 26). Straits Times, p. H11.

Turnbull, C. M. (1995). Dateline Singapore: 150 years of the Straits Times. Singapore: Singapore Press Holdings.
Wallace, C. P. (1995, November/December). Singapore's grip. Columbia Journalism Review, p. 19.

Wong, K. K. (2001). Media and culture in Singapore: A theory of controlled commodification. Cresskill, NJ: Hampton.

Wong, W. K. (2002, November 13). Competition hurting both media groups. Business Times (Singapore), p. 8.

Wong, W. K. (2003, December 6). SPH chairman-TV is a strategic platform for group. Business Times (Singapore), p. 4.

Wong, W. K., \& Lim, K. (2003, November 13). Small media market worsened by price-cutting. Business Times (Singapore), p. 2.

Yap, J. (2004, March 26). Streats steps up free sheet fight with afternoon edition. Media, p. 8. 
Copyright of JMM: The International Journal on Media Management is the property of Lawrence Erlbaum Associates and its content may not be copied or emailed to multiple sites or posted to a listserv without the copyright holder's express written permission. However, users may print, download, or email articles for individual use. 